\title{
Adana ve Çevresinde Radyoaktivite Seviyesi ve Sağlık Riski
}

\author{
Muhammet KARATAŞLI* \\ Beykent University, Faculty of Engineering and Architecture, Department of Electronics and Communication \\ Engineering, İstanbul, Turkey \\ (ORCID: 0000-0002-5893-6800)
}

\section{$\ddot{\mathbf{O} z}$}

Adana İli ve çevresinde havadaki gama radyasyon doz seviyelerini belirlemek için 133 farklı noktada toprak yüzeyinden yaklaşı $1 \mathrm{~m}$ yükseklikte ölçümler yapıldı. Ölçümler, doğal gama radyasyonu ölçümleri ile birlikte serpinti ile birlikte inen düşük aktiviteli radyonüklidlerden yayılan radyasyonun tespitine duyarlı olan portatif bir gama sintilasyon detektörü kullanılarak ölçüldü. Bu çalışmada, Adana ili ve çevresinde bulunan gamma doz seviye ölçümlerinin aritmetik ortalaması $71.2(\mathrm{nGy} / \mathrm{h})$ olarak bulundu. Bu değer yıllık etkin doz eşdeğeri 87.3 $\mu \mathrm{Sv} / \mathrm{y}$ değerinde etkin doz ortalamasına karşılık gelmektedir. Elde edilen sonuçlar, Türkiye'nin farklı bölgelerinde yapılan çalışmalar ve dünya ortalamasıyla karşılaştırılmıştır.

Anahtar kelimeler: Radyasyon, Gama Dozu, Kanser Riski, Yıllık Etkin Doz, Adana

\section{Radioactivity Levels and Health Risks of in and Around the Adana Region, Turkey}

\begin{abstract}
In order to determine the gamma radiation dose levels in the Adana Province and its vicinity, measurements were made at a height of approximately $1 \mathrm{~m}$ from the soil surface at 133 different points. The measurements were measured using a portable gamma scintillation detector that was sensitive to detection of radiation emitted by low-activity radionuclides descending with fallout along with natural gamma radiation measurements. In this study, the arithmetic average of gamma dose level measurements in Adana province and its surroundings was found to be $71.2(\mathrm{nGy} / \mathrm{h}$ ). This value corresponds to the mean effective dose equivalent of $87.3 \mu \mathrm{Sv} / \mathrm{y}$. The obtained results were compared to studies conducted in different regions of Turkey and the world average.
\end{abstract}

Keywords: Radiation, Gamma Dose, Cancer Risk, Annual Effective Dose, Adana.

\section{Introduction}

Radiation is caused by radioactive nuclei in the earth's building, from cosmic rays formed in the solar system, or artificial radiation produced by human beings. The basic source of radiation that people are exposed to in the environment they live in is natural radiation. The investigation of the dose, the effects on people's lifespan, and the harm they will cause is of great importance in the study of environmental radioactivity. The majority of the external gamma dose rate on ordinary soils is due to the primary radio-nuclei in the ground. K-40 (35\%), Th-232 (50\%) and U-238 (15\%) are the main cores that make up the gamma dose in the ground. The predominant gamma dose distribution over soil is due to radioactive materials at depths of $30 \mathrm{~cm}$ of soil. However, uranium and thorium concentrations are higher in some parts of the world, especially in oil regions. There are two important factors that influence the changes, namely radio-nuclear condensation and armor (insulation) [1].

The dose varies according to the radio-nucleus composition in the soil and rocks and the geological structure of the region. Generally, the volcanic rocks have a high dose level, which is

*Sorumlu yazar:muhammet.karatasli@gmail.com

Geliş Tarihi: 17.02.2019, Kabul Tarihi: 01.07.2019 
associated with the high silica (flintstone, quartz sand) amount present in the acidic rocks. Generally, sedimentary rocks have lower radioactive material concentrations in volcanic rocks. Radioactivity in the soil arises from the rocks, where radioactivity can be increased or decreased by sedimentation / dissolution and abrasion with dilution with other materials by sedimentation in groundwater $[2,3,4]$.

The measurement of environmental radiation is very important for determining the amount of natural baseline level of activity change. From here, it can be easily determined whether there is any radioactive pollution and monitoring of the contamination is very important due to environmental protection. Therefore, the main purpose of environmental radiation measurements is to determine the radiation dose and the type of radiation and to evaluate the risk that this radiation will form. The concentration of the radionuclides which form the natural radiation sources in the environment must be determined by the influence on the biological systems, especially in the radiation. This is because irradiation of cells in the background of the radiation can cause DNA damage. Radiation effects against DNA can result in a return to normal structure or can lead to changes that can vary depending on the causes (chromosomal abnormalities and mutations) in surviving cells in DNA [5]. Due to the damages of background radiation, different studies have been carried out to prevent the risk of harm to human health [6].

Therefore, in this study, was investigated in terms of activation concentration and outdoor gamma dose rates of radionuclides in order to reveal the possible potential health risks for Turkey's formably population in the Mediterranean region reveal Turkey's fourth largest city with Adana distribution radyolüsit provincial and local residents.

\section{Materials and Methods}

Adana is located between $35^{\circ}-38^{\circ}$ north latitudes and $34^{\circ}-36^{\circ}$ east longitude and in the Mediterranean Region. As shown in Figure 1, there are 15 towns including Seyhan, Yüreğir, Çukurova, Sarıçam, Aladağ Karaisalı, Ceyhan, Imamoglu, Feke, Pozant1, Karataş, Kozan, Saimbeyli, Yumurtalık and Tufanbeyli. The Adana province borders are one of the interesting aspects of the Taurus belt in terms of covering most of the tectonostratigraphic units of the Taurus, or rock-stratigraphic units representing all systems of the Cambrian-Tertiary space $[7,8]$. The area under investigation is between the Yumurtalık fault and the Ecemi Fay. The region of Adana within the boundaries includes different tectonostratigraphic associations with distinct tectonic contact between them in terms of their distinctive stratigraphy, structure and rocking characteristics.

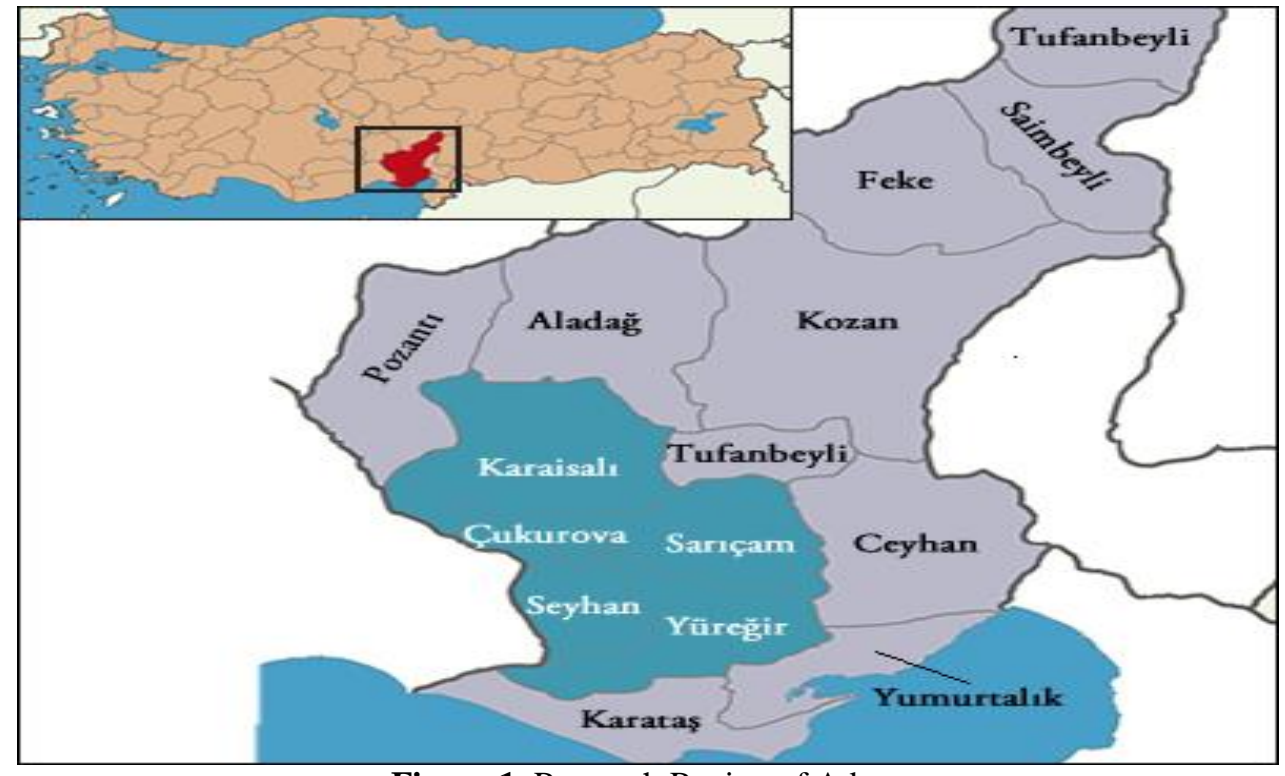

Figure 1. Research Region of Adana

The Bolkar Mountain association includes rocks with olistostrome, along with carbonate and crushed rocks deposited from the Devonian-Lower Tertiary area. The steppe association includes acidic tuffs, basic and ultrabasic rocks and serpentinites, which represent different facies and 
environments ranging from continental pelagic and oceanic rocks deposited in the Triassic-Senonian range to shelf-type rocks. Aladağ unit includes shelf type carbonate and rugged rocks representing the Devonian-Cretaceous interval. Deer Mountain association, carbonate and cratered rocks of the Cambrian-Early Tertiary range. The Görbiyes Mountain association includes carbonate sediments, olistolith and olistostromal formations, possibly representing the Jurassic-Late Cretaceous interval. The Mount of Gorbiyes shows low grade metamorphism. The Keban-Malatya association is represented by the metamorphic, predominantly platform-type metaplastic and metacarbonates with Upper Paleozoic-Lower Cretaceous age range. The Misis-Andirin association, deposited in the Cretaceous-Tertiary time interval, provides mélange-like and volcanosed-sedimentary facies features [9].

In this study, in order to determine the levels of gamma radiation levels in 133 different regions of different parts of Adana province, measurements were taken for 2 minutes at a height of about $1 \mathrm{~m}$ from the ground in the direction of gonads (reproductive organs).

Table 1.

The coordinates of the sample areas, altitude, population and station numbers are shown in

Table 1. Distribution of stations in the research region of Adana

\begin{tabular}{lllllll}
\hline District & $\begin{array}{l}\text { Latitude } \\
(\mathrm{N})\end{array}$ & $\begin{array}{l}\text { Longitude } \\
(\mathrm{E})\end{array}$ & Altitude $(\mathrm{m})$ & $\begin{array}{l}\text { Catchment } \\
\text { area }\left(\mathrm{km}^{2}\right)\end{array}$ & Population & $\begin{array}{l}\text { Number } \\
\text { Stations }\end{array}$ \\
\hline Kozan & $37.45^{\circ}$ & $35.81^{\circ}$ & 110 & 1690 & 130456 & 10 \\
Aladağ & $37.54^{\circ}$ & $35.39^{\circ}$ & 850 & 1347 & 15896 & 8 \\
Pozantı & $37.42^{\circ}$ & $34.87^{\circ}$ & 780 & 946 & 19215 & 9 \\
Çukurova & $37.04^{\circ}$ & $35.30^{\circ}$ & 23 & 240 & 364118 & 5 \\
Sarı̧çam & $37.01^{\circ}$ & $35.38^{\circ}$ & 100 & 770 & 163833 & 7 \\
Yüreğir & $36.98^{\circ}$ & $35.33^{\circ}$ & 27 & 1538 & 424999 & 14 \\
Seyhan & $36.97^{\circ}$ & $35.33^{\circ}$ & 23 & 444 & 800387 & 10 \\
Karataş & $36.56^{\circ}$ & $35.38^{\circ}$ & 10 & 862 & 22098 & 9 \\
Yumurtalık & $36.76^{\circ}$ & $35.72^{\circ}$ & 18 & 447 & 17211 & 13 \\
Ceyhan & $37.02^{\circ}$ & $35.81^{\circ}$ & 20 & 1472 & 160616 & 26 \\
Tufanbeyli & $38.26^{\circ}$ & $36.22^{\circ}$ & 1474 & 964 & 16640 & 5 \\
Saimbeyli & $37.98^{\circ}$ & $36.09^{\circ}$ & 971 & 989 & 14840 & 4 \\
Feke & $37.81^{\circ}$ & $35.91^{\circ}$ & 620 & 1116 & 16572 & 7 \\
Imamoğlu & $37.26^{\circ}$ & $35.66^{\circ}$ & 76 & 445 & 28405 & 6 \\
\hline
\end{tabular}

The results of the gamma irradiation rates that were absorbed by the Eberline Smart Portable (ESP-2) device in open air were obtained in $\mu \mathrm{R} / \mathrm{h}$. The results obtained were converted to the absorbed dose rate $\mathrm{nGy} / \mathrm{h}$ using a conversion factor from the definition of Rontgen $(8.7 \mathrm{nGy} / \mu \mathrm{R})$ [10].

Equation 1 was found to be equivalent to the annual effective dose (AEDE ) [11, 12].

$$
\mathrm{AEDE}=\mathrm{ADRA} * \mathrm{OF}^{*} \mathrm{DCF} * \mathrm{~T}
$$

Here, ADRA is the rate of gamma radiation dose absorbed in the air DCF is the environmental gamma dose conversion factor, the occupation factor is $\mathrm{OF}, \mathrm{T}$ is the time. The environmental gamma dose conversion factor was determined to be $0.7 \mathrm{~Sv} / \mathrm{Gy}$ to convert the absorbed dose ratio to the annual effective dose equivalent. In addition, $20 \%$ of the people spent in the field during a year (8760 $\mathrm{h} / \mathrm{y}$ ) was spent in open areas, taking into consideration the coefficient of occupation 0.2 Lifetime cancer risk (ELCR) was calculated using Equation 2 after finding the annual effective dose value $[12,13]$.

\section{$\mathrm{ELCR}=\mathrm{AEDE} * \mathrm{DL} * \mathrm{RF}$}

Here, DL is the average duration of life (mean 70 years) and RF is a risk factor and for stochastic effects. ICRP risk factors for lethal cancer in the whole population are used respectively (1 / Sv), RF for ICRP 103, BEIR VII [14] and ICRP 60 for 0,057, 0,064 and 0,072 values [15].

In this study, Eberline Smart Portable (ESP-2) model, portable microcomputer and a SPA-6 plastic scintillation detector connected device were used to determine the external gamma radiation 
levels. ESP-2 is a device specially designed for radiation measurements, which can record the measured information and then transfer the information recorded to a connected printer.

\section{Results and Discussion}

Table 2 shows the minimum, maximum and average values of gamma exposure dose ratio and absorbed dose ratio for each district of the Adana.

The arithmetic mean of the gamma dose measurements performed in 133 different regions in Adana and its vicinity was calculated as $71,2 \mathrm{nGy} / \mathrm{h}$.

Table 2. Gama exposure dose rate and absorbed dose rate for each distinct of the Adana

\begin{tabular}{lllllll}
\hline & \multicolumn{2}{l}{$\begin{array}{l}\text { GEDR }(\text { Gamma Exposure Dose Rate) } \\
(\mu \mathrm{R} / \mathrm{h})\end{array}$} & \multicolumn{3}{l}{$\begin{array}{l}\text { ADRA (Absorbed Dose Rate in Air) } \\
(\mathrm{nGy} / \mathrm{h})\end{array}$} \\
District & Minimum & Maximum & Mean & Minimum & Maximum & Mean \\
\hline Kozan & 10.3 & 16.8 & 13.1 & 89.6 & 146 & 114 \\
Aladağ & 2.97 & 9.62 & 6.47 & 25.8 & 83.7 & 56.3 \\
Pozantı & 6.46 & 13.5 & 9.98 & 56.2 & 118 & 86.8 \\
Çukurova & 6.10 & 7.78 & 6.98 & 53.1 & 67.7 & 60.8 \\
Sarıçam & 5.02 & 7.64 & 6.35 & 43.7 & 66.5 & 55.2 \\
Yüreğir & 4.36 & 8.37 & 6.76 & 37.9 & 72.8 & 58.8 \\
Seyhan & 5.84 & 9.51 & 7.84 & 50.8 & 82.7 & 68.2 \\
Karataş & 5.12 & 9.10 & 6.90 & 44.5 & 79.2 & 60 \\
Yumurtalık & 5.24 & 8.99 & 6.50 & 45.6 & 78.2 & 56.6 \\
Ceyhan & 4.66 & 9.87 & 7.41 & 40.5 & 85.9 & 64.5 \\
Tufanbeyli & 10.2 & 12.3 & 11.6 & 88.7 & 107 & 101 \\
Saimbeyli & 11.1 & 13.9 & 12.6 & 96.6 & 121 & 110 \\
Feke & 6.37 & 15.4 & 8.97 & 55.4 & 134 & 78 \\
Imamoğlu & 6.80 & 9.5 & 8.74 & 59.2 & 82.7 & 76 \\
Region & 2.97 & 8.18 & 13.1 & 25.8 & 146 & 71.2 \\
\hline
\end{tabular}

In Figure 2, the absorbance gamma dose map obtained from measurements for Adana province and its surroundings is plotted. The overall distribution of the gamma dose rate absorbed in Figure 2 is in the form of an isodose map. The red areas represent areas where the absorbed gamma dose values in Adana province and in general are high.

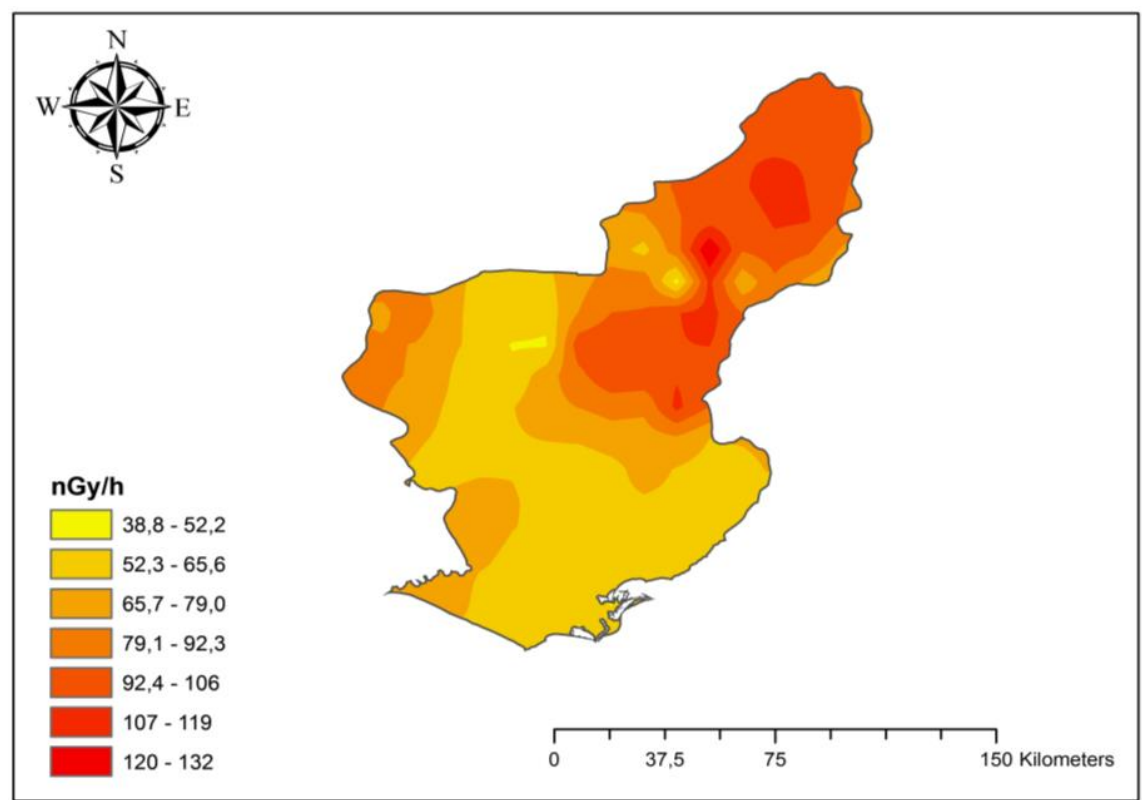

Figure 2. ADRA in Adana 
The mean value of the annual effective dose calculated using external gamma dose was found to be $87.3 \mu \mathrm{Sv} / \mathrm{y}$. This value is higher than the world average of $70 \mu \mathrm{Sv} / \mathrm{y}$ [11]. The average annual effective dose values (AEDE) arising from average measured absorbed gamma dose rates in air (ADRA) for each districts of Adana and the estimated lifetime cancer risk values in public using three different models are given in Table 3.

Table 3. The average annual effective dose values and lifetime cancer risk

Lifetime cancer risk \%

\begin{tabular}{|c|c|c|c|c|}
\hline & $\begin{array}{l}\mathrm{AEDE} \\
(\mu \mathrm{Sv} / \mathrm{y}\end{array}$ & ICRP 103 & BEIR VII & ICRP 60 \\
\hline Kozan & 140 & 0.056 & 0.063 & 0.070 \\
\hline Aladağ & 69 & 0.028 & 0.031 & 0.035 \\
\hline Pozant1 & 106 & 0.042 & 0.047 & 0.053 \\
\hline Çukurova & 74.6 & 0.030 & 0.033 & 0.038 \\
\hline Sarıçam & 67.7 & 0.027 & 0.030 & 0.034 \\
\hline Yüreğir & 72.1 & 0.029 & 0.032 & 0.036 \\
\hline Seyhan & 83.6 & 0.033 & 0.037 & 0042 \\
\hline Karataş & 73.6 & 0.029 & 0.033 & 0.037 \\
\hline Yumurtalık & 69.4 & 0.028 & 0.031 & 0.035 \\
\hline Ceyhan & 79.1 & 0.032 & 0.035 & 0.040 \\
\hline Tufanbeyli & 124 & 0.049 & 0.056 & 0.062 \\
\hline Saimbeyli & 135 & 0.054 & 0.060 & 0.068 \\
\hline Feke & 95.7 & 0.038 & 0.043 & 0.048 \\
\hline Imamoğlu & 93.2 & 0.037 & 0.042 & 0.047 \\
\hline Region & 87.3 & 0.035 & 0.039 & 0.044 \\
\hline
\end{tabular}

These calculated values may vary depending on altitude, weather conditions, outdoor exposure time and humidity. The mean cancer risk values calculated using equation 2 in Adana and its vicinity were found as $0.035,0.044$ and 0.039 for ICRP 103, ICRP 60 and BEIR VII, respectively. 
Table 4. ADRA and AEDE values

\begin{tabular}{lll}
\hline & $\begin{array}{l}\text { ADRA } \\
(\mathrm{nGy} / \mathrm{h})\end{array}$ & $\begin{array}{l}\text { AEDE } \\
(\mu \mathrm{Sv} / \mathrm{y})\end{array}$ \\
\hline İstanbul [17]. & 65 & 79.7 \\
Şanlıurfa [18]. & 60.9 & 74.7 \\
Kastamonu [19]. & 54.81 & 67.21 \\
Kırklareli [20]. & 118 & 144.7 \\
Çanakkale [21]. & 66.4 & 81.4 \\
Tekirdağ [22]. & 43.85 & 53.77 \\
Trabzon [23]. & 59 & 72.4 \\
Çankırı [24]. & 69.6 & 87.7 \\
Yalova [25]. & 84 & 103 \\
Balıkesir [26]. & 127 & 155.8 \\
Kahramanmaraş [27]. & 64.8 & 79.5 \\
Hatay [28]. & 61.9 & 75.91 \\
Adana [11]. & 71.2 & 87.3 \\
Dünya & 60 & 70 \\
\hline
\end{tabular}

The absorbed dose rates and annual effective gamma doses were also determined much higher than the world's averages in terms of health effects of background radiations. These calculated mean values are considerably smaller than the $1 \mathrm{mSv} / \mathrm{y}$ value determined by the ICRP as the limit value of the annual effective dose equivalent [16]. The mean ADRA value observed in the study area is lower than other cities and the world average due to the low radionuclide concentration seen in the area as can be seen in Table 4 .

\section{References}

[1] Jibiri, N.N. 2001. Assessment of Health Risk Levels Associated with Terrestrial Gamma Radiation Dose Rates in Nigeria. Enviromental International, 27 (1): 21-26.

[2] Nada A. 2003. Evaluation of Natural Radionuclides at Um-Greifat Area, Eastern Desssert of Egypt. Applied Radiation and Isotopes, 58 (2): 275-280.

[3] Hakam O.K., Choukri A., Moutia Z., Chouak A., Cherkaoui R., Reyss J.L., Lferde M. 2001. Uraniumand Radium in Groundwater and Surface Water Samples Morocco. Radiation Physics and Chemistry, 61 (3-6): 653-654.

[4] Aburamad K.M., Al-Tamimi M. 2001. Emanation power of radon and its concentration in soil and rocks. Radiation Measurements, 34 (1): 423-426.

[5] Kapdan E., Altinsoy N., Karahan G., Taskin H. 2011. Determination of the health hazards due to background radiation sources in the city of Adapazari, Northwestern Turkey. Isotopes in Environmental and Health Studies, 47 (1): 93-100.

[6] Kapdan E., Varinlioglu A., Karahan G. 2011. Outdoor Radioactivity and Health Risks in Balıkesir, Northwestern Turkey. Radiat Prot Dosim, 148 (3): 301-309.

[7] Kop A. 2003. Tectono-Stratigraphy and Structural Evolution of Gokcekoy-Kıslak-MenkezAkdam (D-Kd Aladag, Adana). Ph.D. Thesis, Department of Geology Institute of Natural and Applied Sciences University of Cukurova, $311 \mathrm{p}$.

[8] Usta D., Şenel M., Metin Y., Bedi Y., Vergili Ö., Usta M., Balcı V., Kuru K., Tok T., Özkan M.K., Kop A. 2004. TJK Abstract Essentials, 275.

[9] M.T.A. 2006. Adana İli Jeolojik Özellikleri. https://docplayer.biz.tr/6465236-Maden-tetkik-vearama-genel-mudurlugu-dogu-akdeniz-bolge-mudurlugu-adana-ili-jeolojik-ozellikleri.html (Accessed 19.01.2019), 
[10] Baykara O. 2005. The determinations of natural radioactivity in the intersect zone of the North Anatolian Fault and East Anatolian. PhD thesis, Fault, Firat University Graduate School of Natural and Applied Science, Elazig, Turkey (in Turkish), 90 p.

[11] UNSCEAR. 2000. Report of the United Nations Scientific Committee on the Effects of Atomic Radiation, Sources, Effects, and Risks of Ionizing Radiation. United Nations sales publication, New York. United Nations.

[12] Karataşlı M., Turhan Ş., Varinlioğlu A., Yeğingil Z. 2016. Natural and fallout radioactivity levels and radiation hazard evaluation in soil samples. Environ. Earth Sci., 75 (5): 1-9.

[13] UNSCEAR. 2008. Report of the United Nations Scientific Committee on the Effects of Atomic Radiation, Sources, Effects, and Risks of Ionizing Radiation. United Nations sales publication, New York, United Nations.

[14] NCR. 2006. National Academy of Sciences. National Research Council Committee to Assess Health Risks from Exposure to Low Levels of Ionizing Radiation. Report of VII.

[15] ICRP. 2007. Publication 103 Recommendations of the ICRP: Annals of the ICRP (International Commission on Radiological Protection), 37/2-4.

[16] ICRP. 1990. The International Commission on Radiological Protection, ICRP Publication 60. Recommendations of the International Commission on the Radiological Protection, Pergamon Press Inc., ICRP, USA.

[17] Karahan G., Bayulken A. 2000. Assesment of Gamma Dose Rates Around Istanbul. Journal of Envrionmental Radioactivity, 47 (2): 213-221.

[18] Bozkurt, A., Yorulmaz, N., Kam, E., Karahan, G. and Osmanlığlu, A. E. 2007. Assessment of environmental radioactivity for Şanliurfa region of southeastern Turkey. Radiation Measurements, 42 (8): 1387-1391.

[19] Kam E., Bozkurt A. 2007. Environmental radioactivity measurements in Kastamonu region of northern Turkey. Applied Radiation and Isotopes, 65 (4): 440-444.

[20] Taskin H., Karavus M., Ay P., Topuzoglu A., Hidiroglu S., Karahan G. 2009. Radionuclide concentrations in soil and lifetime cancer risk due to gamma radioactivity in Kirklareli, Turkey. Journal of Environmental Radioactivity, 100 (1): 49-53.

[21] Kam E., Bozkurt A., Ilgar R. 2010. A study of background radioactivity level for Canakkale, Turkey. Environ. Monit. Assess, 168 (1-4): 685- 690.

[22] Kam E., Yarar Y., Bozkurt A. 2010. A study of background radioactivity level for Tekirdag. Turk Radiat Prot Dosimetry, 138 (1): 40-44.

[23] Kurnaz A., Kucukomeroglu B., Damla N., Cevik U. 2011. Radiological maps for Trabzon. Turkey. J. Environ. Radioactiv, 102 (4): 393-399.

[24] Kapdan E., Taşkın H., Kam E., Osmanlığlu A.E., Karahan G., Bozkurt A. 2011. A study of environmental radioactivity measurements for Cankiri, Turkey. Radiation Protection Dosimetry, 150 (3): 398-404.

[25] Kapdan E., Varinlioglu A., Karahan G. 2011. Radioactivity Levels and Health Risks due to Radionuclides in the Soil of Yalova, Northwestern Turkey. International Journal of Environmental Research, 5 (4):837-846.

[26] Kapdan E., Varinlioglu A., Karahan G. 2012. Outdoor radioactivity and health risks in Balikesir, Northwestern Turkey. Radiation Protection Dosimetry, 148 (3): 301-309.

[27] Karataşlı M. 2019. Determination of Outdoor Absorbed Gamma Dose Rates of Kahramanmaraş Province, Turkey. Cumhuriyet Science Journal, 40 (1): 102-107.

[28] Karataşlı M. 2018. Measurement of Environmental Gamma Radiation in and Around The Hatay Province, Turkey. Afyon Kocatepe University Journal of Science and Engineering, 18 (3): 780785. 